\title{
AFC との協調制御を考慮したEDCの実用化
}

\begin{tabular}{|c|c|c|c|c|}
\hline 亘小鳥 & 康弘 ${ }^{*}$ & & 员 & 中朴 \\
\hline 員 阿部 & 公哉** & 正 & 員 & 高标 \\
\hline & 英一 & & 員 & \\
\hline
\end{tabular}

Development of EDC Considering Cooperation with AFC

Yasuhiro Kojima*, Member, Shizuka Nakamura*, Member, Kinya Abe ${ }^{* *}$, Member,

Osamu Takahashi**, Member, Eiichi Tsukada**, Member, Takahisa Kurokawa***, Member

This paper presents a newly developed EDC (Economic Dispatching Control) function for Tohoku EPCO's new EMS system. In this new EDC, we can minimize total fuel cost under system security constraints such as "AFC margin considering band width and ramp rate in future band changing schedule" and "power flow constraint considering future maintenance schedule". We formulate EDC problem as "continuous variable (generator output) optimization" under "combinatorial optimization of band schedule". To optimize this problem, Problem Space Search method and interior point QP method are adopted. Test results and the actual operation show that, this new EDC can follow against steep increase and decrease of electric demand cooperating with AFC. This EDC has been operating successfully in Tohoku EPCO since June 2003.

キーワード： EDC, ELD, 最適経済負荷配分, AFC 容量, 組み合わせ最適化, 内点法 QP

Keywords: economic dispatching control, ELD, AFC margin, combinatorial optimization, interior point QP

\section{1. はじめに}

電気事業を取巻く環境は，電力自由化の進展などに伴い 激しく变化し, 電力会社の需給運用は下記のような課題を かかえている。

・アンシラリサービスを確保した上での経済性追求

・選択的設備投資に起因する系統構成複雑化，および作 業停止時の系統制約の増加

- 電源多樣化に伴う運用制約の増加

このような環境下において, 時々刻々变化する運用条件の

もとで種々の制約に適応できる EDC (経済負荷配分制御) の実現か望まれていた。

これまでに，電力各社では，多くの EDC が開発されて

* 三菱電機 (株)

于 661-8661 尼崎市塚口本町 8-1-1

Mitsubishi Electric Corp.

8-1-1, Tsukaguchi-honmachi, Amagasaki 661-8661

** 東北電力 (株)

₹ 980-0014 仙台市青葉区本町 1-7-1

Tohoku Electric Power Co., Inc.

1-7-1, Honmachi, Aoba-ku, Sendai 980-0014

*** ティーエム・ティーアンドディー (株)

₹ 183-0075 府中市晴見町 2-24-1

TM T\&D Corp.

2-24-1, Harumi-cho, Fuchu 183-0057
いる(1)。これらは, 主として火力発電機を経済的に運用す ることを目的にしており，等入法が適用されてきた。近年 は,計算機能力の向上に伴い,負荷追従性を確保した最適経 済負荷配分を行うために, 将来を含めた複数時刻断面での 需給バランスを考慮可能な 2 次計画法が適用され始めてい る。しかし，2 次計画法は目的関数や制約条件の定式化が 難しく, より自由度の高い手法の開発が望まれていた。光 こでわれわれは, 東北電力の中央給電指令所システム更新 に伴い，組み合わせ最適化手法と 2 次計画法を適用する事 で, 各種制約条件に柔軟に対応する事が可能な EDC を開 発・実用化 ${ }^{(2) \sim(5)}$ したので報告する。

本システムでは, 将来最大 8 時間程度先までの多時刻断 面において, 各発電機の運用条件 (出力上下限・变化速度 等) と出力予定值から断面毎の AFC 容量を定式化し，制 約条件として組み込んでいる。これにより，需要の変化や $\mathrm{EDC}$ 対象外供給力の出力変更などに起因する需給アンバラ ンスに対しては,確保した AFC 容量を有効に活用しながら $\mathrm{AFC}$ 機能により追従する。連動試験では, 負荷変動の大き な朝の立ち上がり・昼休み・点灯帯を含め自動経済負荷配 分制御が可能であることか確認できた。以下では，中給シ ステムの概要に触れた後, EDC 問題を定式化し, 最後に実 動作状況について報告する。 


\section{2. 中給システムにおける EDC の位置づけ}

新中央給電指令所システムは, オープン分散システムで 構成される。EDC 機能は, 当日の状況に合わせた各種制約 条件を考慮した上で経済メリットを追求するため，図１に 示すようにオンライン・支援系の各機能と連係している。

支援系の各機能（作業停止計画，需給運用計画，系統運 用計画）は，年間・月間・週間・翌日の各フェーズにおい て，機能間で連係しながら計画を立案しており，オンライ ン系には最終的な翌日運用計画の結果を引継ぐ。

需給運用計画機能からは, 総需要予想, EDC 対象外の供 給力予想，各発電機の起動停止計画や作業スケジュール， LNG 燃料消費計画等の供給力関連情報を引継ぎ，EDC 計 算への入力情報とする。作業停止計画機能からは，作業停 止設備情報を引継ぎ，将来断面作製機能か現在の系統状態 を起点とした将来系統断面を作成する(詳細は文献 (3) を 参照)。EDC・系統制御 $(\mathrm{LPC}, \mathrm{VQC}) \cdot$ 信頼度監視の各機 能では，この将来系統構成を扱うことで, 当日の実系統状 態を反映した将来系統状態の監視・制御が可能となる。ま た EDC・系統制御機能では, 系統運用計画機能および信頼 度監視機能からは想定事故・安定度検討に基づく運用制約 を引き継ぎ，制約条件として使用する。

$\mathrm{EDC}$ 機能は, 上述の各機能から引継いだ制約条件のもと， 当日の需要実績や系統状態に応じて, 制約条件を遵守した 発電機の経済負荷配分制御を 3 分周期で実施する。また, 東北電力の電源構成は補機切替時間の長い石炭火力および 燃料消費量制約が厳しい LNG 火力の比率が高いため, こ れらの運用制約を加味した最適化が自動制御実現のために は不可欠である。

また, $\mathrm{EDC}$ 機能か対象とする需要変動は数十分から日レ ベルである。これより短周期の需要変動に対しては, $\mathrm{AFC}$ 機能が地域要求量 (AR) を解消するよう 5 秒周期でPI 制

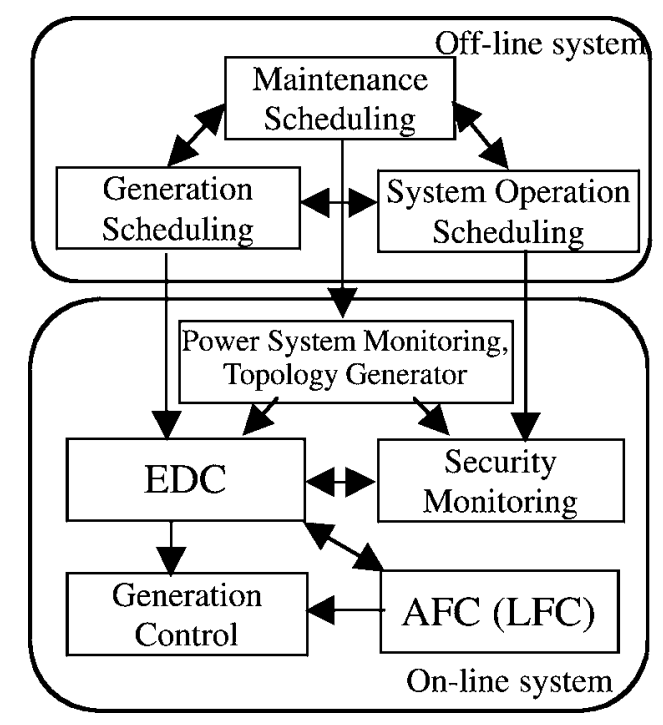

图 $1 \mathrm{EDC}$ 機能と各機能との連係

Fig. 1. EDC and other functions.
御に基づく $\mathrm{AFC}$ 指令値を各発電機に出力しており，この 両制御機能の協調が重要である。以下の章では, EDC の定 式化ならびに $\mathrm{AFC}$ との協調制御の考え方，および，実連動 試験による検証結果について述べる。

\section{EDC 問題の定式化}

〈3. 1〉 概要 本システムの EDC は, 以下の機能を実 現する。

- 発電機に対する出力値指令は連続值と離散值の 2 種類 の発電機が存在する。また , バンド切り替え指令も実 施する。

- 各種制約条件 (出力上下限制約, 变化速度制約, 潮流 制約，燃料消費量制約，AFC 容量制約等）を遵守した 上で, 最経済な計画を立案する。

この最適経済負荷配分問題は, バンド状態ならびに離散 值指令を決定する離散值最適化問題と, 各発電機の連続値 出力を決定する連続値最適化問題の二重の最適化問題とし て定式化できる (図 2 参照)。

〈3. 2〉 離散值最適化問題発電機のバンドは, 連動バ ンド $(\mathrm{H}, \mathrm{M}, \mathrm{L})$, および除外バンド (最大, 最低) から なる。連動バンドではバンド内で連続值出力指令が可能で あるのに対し, 除外バンドでは指令值はいくつかの離散值 に限定される。また各バンド境界では保持時間制約を考慮 する必要がある (図 3 参照)。離散值指令は除外バンドと同 樣に扱うことが可能である。

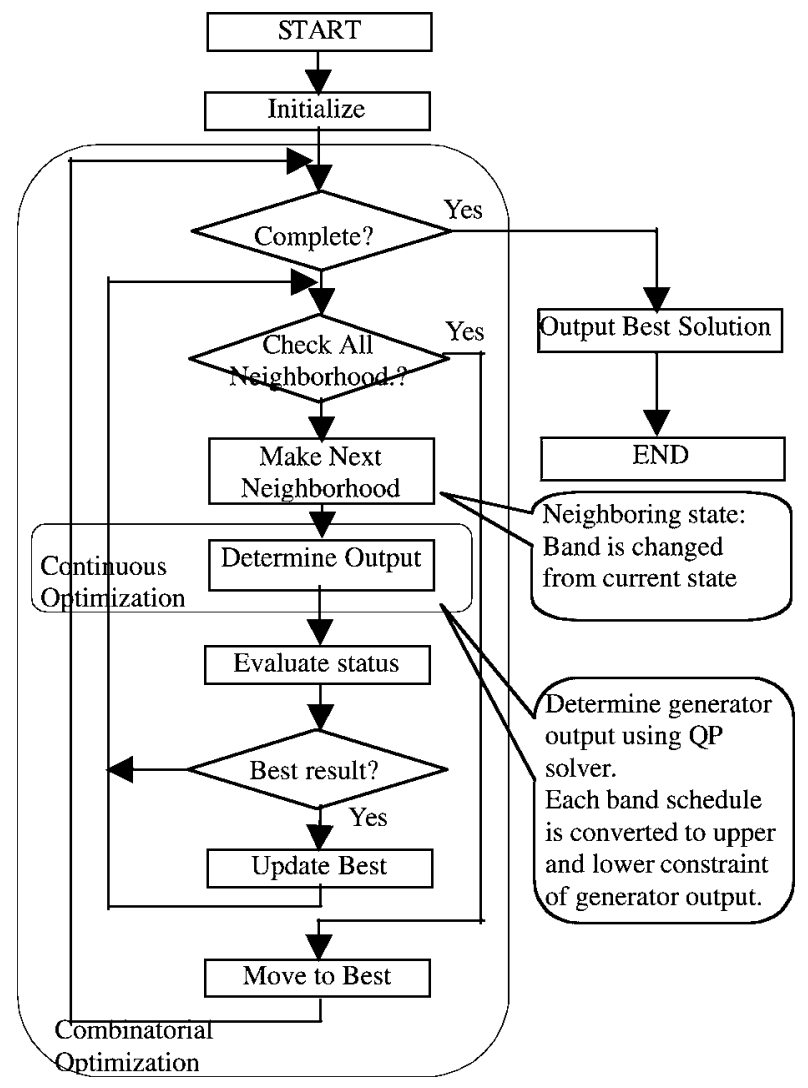

図 $2 \mathrm{EDC}$ 機能の概略フロー

Fig. 2. Flow chart of EDC function. 


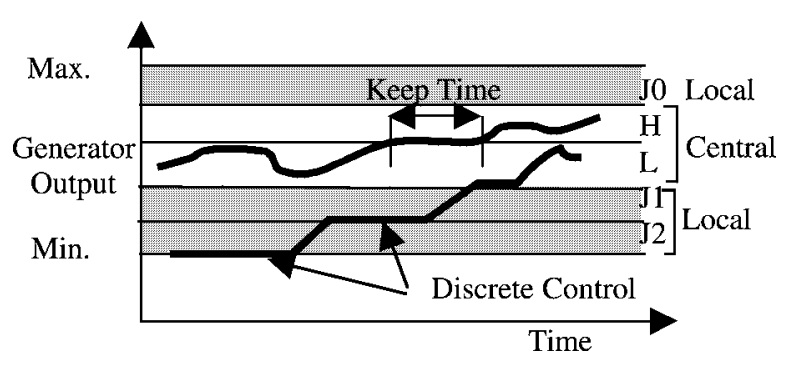

図 3 発電機のバンド制約の考え方

Fig. 3. Band constraint for generator control.

今回, 離散値の最適化問題には, 連続值最適化問題との 組み合わせに適した問題空間探索法を採用した。この組み 合わせ最適化問題では,「状態」を各発電機の各時刻におけ るバンド值（すなわちバンド切り替えスケジュール）であ ると定義し, 現在状態から关の隣接状態のうち評価関数值 が最小となる隣接状態への遷移を繰り返すことで, 評価関 数值が最小となるようにバンド切り替えスケジュールを決 定する (解のサイクリングの防止策等は参考文献 (6) 参照)。

隣接状態は各発電機に対するバンド切り替えの追加/変更/ 削除で表現される。ただし，探索を効率化するために，例 えば以下のような各制約条件違反の解消およびコスト最適 化を目的とした隣接状態を定義している。

・コスト最適化：連続出力指令值がバンドの上 (下) 限 に張り付いている時間帯のバンドを上げる (下げる)。

・需給バランス違反 : 上げ・下げ方向に余裕のある発電 機のバンドを上げる・下げる。切り替え時間を前後に 変更する。

- 潮流制約違反 : 違反量と各発電機の潮流感度から，効 果のある発電機のバンドを必要量だけ上げ・下げする。 離散值最適化問題の評価関数值は，バンド状態を制約条 件とした連続值最適化問題の最適解における発電機燃料コ ストと各制約条件違反量の重要度に応じた重み付け和とす る (詳細は次節)。探索は，現在状態に対する全隣接状態の 評価関数を計算し, 弚のうちの評価関数值が最良の隣接状 態に遷移することを規定回数もしくは制限時間内で繰り返 す。なお, 最良隣接状態の選択には, 複数の隣接状態の組 み合わせ処理を行い，探索の効率化を図っている。

〈3. 3〉 連続值最適化問題 離散值最適化問題から与え られたバンド状態により各時刻の発電機上下限が決まるの で，発電機出力決定問題は制約条件のもとでの燃料コスト 最小化を目的とした連続值最適化問題となる。多時刻断面 を考慮した EDCでは，次のように目的関数，制約条件を 定式化できる。連続值最適化問題の解法としては，内点法 QP を用いている。

[目的関数]

$$
\min \underbrace{\sum_{g \in G, t \in T}\left(a_{g} P_{g t}^{2}+b_{g} P_{g t}+c\right)}_{\text {燃料コスト }}+\underbrace{\sum(W \times \text { Vio. })}_{\text {ペナルティ }}
$$

$P_{g, t}:$ 時刻 $\mathrm{t}$ における発電機 $\mathrm{g}$ の出力

各発電機の燃料係数 $\left(a_{g}, b_{g}, c_{g}\right)$ は, オンラインの状態 推定結果に基づき，各発電機の送電ロス率計算を行い補正 している。Vio は以下の各制約条件の違反量，Wは重みで ある。

\section{[制約条件]}

\section{(1) 発電機上下限制約}

$$
P \max _{g t}>P_{g t}>P \min _{g t}
$$

$P \max , P \min _{g t}$ : 時刻 $t$ における発電機 $g$ の上下限 上下限制約は, バンド毎の上下限值, 運用者設定された上 下限值, 出力固定制約から最も厳しいものが各時刻毎に選 択される。作業に伴う出力固定の場合は, 事前に出力が固 定值に到達するよう制約を前倒ししている。

\section{(2) 変化速度制約}

$$
Y \max _{g t}>P_{g t}-P_{g, t-1}>-Y \max _{g t}
$$

$Y \max _{g t}$ : 時刻 $t$ における発電機 $g$ の変化速度上限值。 バンド毎に異なる。

\section{（3）潮流制約}

$$
F \max _{l, t}>F 0_{l t}+\sum_{G} k_{t, l, g} P_{g t}>-F \max _{l, t} \ldots \ldots
$$

$F \max _{l, t}$ : 時刻 $t$ における線路 $l$ の潮流制約值 $F 0_{l, t}:$ 時刻 $t$ における線路 $l$ のベース潮流値

$k_{t, l, g}$ : 時刻 $t$ における線路 $l$ の発電機 $g$ に対する感度値 潮流制約違反解消については，LPCによるループ潮流制御 を優先とする。すなわち，任意の断面で過負荷発生が予想 される場合，LPC タップを制御対象とした過負荷解消のた めの OPF 計算を実行する。この OPF による未解消潮流制 約の違反解消を EDC の制約条件として与える。

(4) 需給バランス制約

$$
L_{t}=\sum_{G} P_{g t}
$$

$L_{t}:$ 時刻 $t$ の制御対象発電機の需要分担量合計

（5）燃料消費制約

$$
\operatorname{Total}_{D}=\sum_{D, T} P_{g t} \cdot
$$

$\operatorname{Total}_{D}$ : 燃料消費制約グループ $D$ の $\mathrm{EDC}$ 計算対象期 間全体での燃料消費目標量

（6）AFC 容量制約（式は上方向容量。下方向も同樣）

$$
\left.\begin{array}{l}
x_{g t}<P \max _{g t}-P_{g t} \\
x_{g t}<Y \max _{g t} \times T_{a f c} \\
\sum_{G} x_{g t}>A F C_{t}
\end{array}\right\}
$$

$x_{g t}:$ 時刻 $t$ に発電機 $g$ で確保可能な $\mathrm{AFC}$ 容量 $T_{a f c}: \mathrm{AFC}$ 容量計算時間 (例えば 5 分) $A F C_{t}$ : 時刻 $t$ における $\mathrm{AFC}$ 容量制約值 




(*) Xmax="Output Ramp Rate" $\times$ "AFC Time"

图 $4 \mathrm{AFC}$ 容量の考え方 (上げ方向の場合)

Fig. 4. AFC margin (Upper margin).

(7) 式は図 4 に示した各発電機毎の AFC 容量を表現して いる。

制約条件のうち, ( 1 )発電機上下限制約と ( 2 )変化速度制 約は絶対制約，光の他の制約はペナルティ制約として反映 し ,ペナルティ制約の重みは下記の順位にて考慮している。

線路潮流 > 需給バランス $\gg \mathrm{AFC}$ 容量, 燃料消費量

なお， $\mathrm{AFC}$ 容量と燃料消費量制約の順位は運用者により指 定可能とした。

\section{EDC 実運用化}

〈4 1〉 AFCとの協調制御 本中給システムの自動需 給制御では，以下の動作原理で $\mathrm{EDC}$ と $\mathrm{AFC}$ が協調制御を 行っている (図 5 参照)。

（1）EDCは，必要な AFC 追従可能量を確保するよう， 3 分周期で 6 分後の火力分担量 (総需要予想值 - 制御対象 外供給力予定值) に対する各発電機の配分を計算し，次の 3 分に各火力発電機にベース値として指令する。指令後, 発 電機出力は指令值に向かって追従していく。

（2）総需要誤差およびEDC 以外の供給力の想定とのず


を 0 とするよう, 各発電機に対し変化速度優先で出力指令 を行う。

(3) 次の $\mathrm{EDC}$ 計算時, EDC 指令値に対して $\mathrm{AFC}$ に より補正された量を EDC の予定分担量に加算し，EDCに て経済性を考慮して再配分する。

すなわち, 本システムの特徵は, 各発電機の変化速度・上 下限制約值から算出される将来の $\mathrm{AFC}$ 追従可能容量を確 保した出力配分を行うことある。このため, 不確定な需要 变動や予測誤差に対して $\mathrm{AFC}$ が追従不能となることがな く，常にAFC と EDC の協調制御が可能となる。図 6 に， $\mathrm{EDC}$ 指令值 (合計)，確保している $\mathrm{AFC}$ 容量および総需要 の実績例を示す。

〈4 2〉自動補正ならびに運用者による介在 当日の運 用では, 予想総需要のずれ，一時的な需要変動等各種の要 因で自動補正ならびに運用者の介在が必要となることがあ る。本システムでは，自動制御を継続しながら以下の補正 を可能としている。

（1）総需要補正 1 日 2 回, 当日総需要予測結果 (1 時間値) に従いEDC で使用する総需要予測カーブ (3 分值)

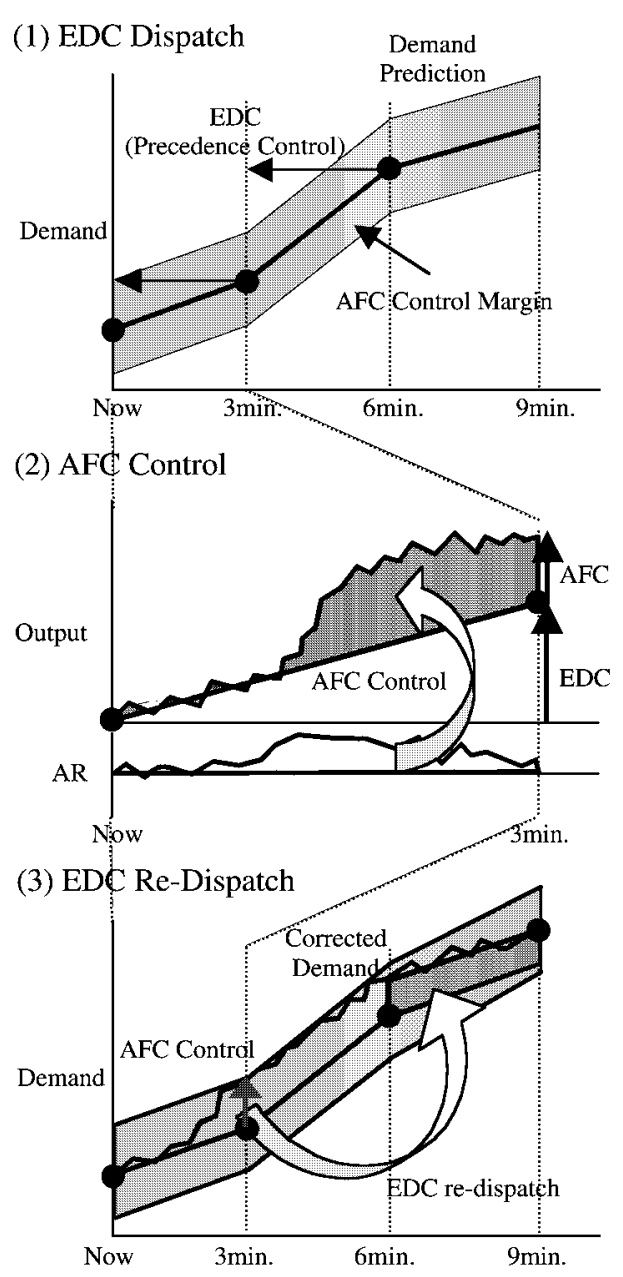

図 $5 \mathrm{EDC}$ と $\mathrm{AFC}$ の協調制御

Fig. 5. Cooperative control of EDC and AFC.



図 6 総需要誤差と EDC による $\mathrm{AFC}$ 容量

Fig. 6. An example of Demand and AFC margin.

を自動作成し，運用者に提示する。EDCへの反映は運用者 の確認・登録を経て実施している。なお，総需要補正は運 用者による任意変更も可能である。

（2）分担量補正運用者が EDC による制御量を操 
作するために，次回 EDC 計算時に用いる分担量を指定量 調整することが可能である。

(3) 出力指令変更発電機を EDC による自動制御 モードから変更することなく, EDC 対象発電機に対して運 用者が直接出力指令変更を行う事を可能とした。この場合， 次回の EDC 計算以降で新指令值を起点として経済性を考 慮して再配分を行う。

〈4.3〉 EDC 計算条件 火力発電機の最低出力から最 大出力まで全ての出力範囲を EDC 対象とすることで, 起 動/停止の過程をの光いた全時間帯を EDC 制御対象とした。 このため, EDC で考慮すべき将来の計算対象期間は，深夜 は発電機出力を一旦最低出力まで落とし再度連動バンドに 上げるまでの時間よりも長くする必要がある。本 EDCで は, 東北電力の火力機の中で最も長い時間である 8 時間と した。昼間については, 出力調整に活用する幅が最低除外 バンドの一部までに限定できるため, 計算対象時間を若干 短縮し，5 時間に設定した。

また，計算の時間刻みは，将来 30 分先までは 3 分固定， 弚れ以降は火力分担量の变化により可変とし, 最長で 15 分 とした。これにより，1 回の EDC 計算における平均的な時 刻断面数は 40 から 45 程度となる。

\section{5. 検証結果}

実運用に至るまでに，オンラインデータを用いたオフラ イン検証，連動試験，試運用の 3 段階で EDC の性能評価 を行った。

〈5 1〉オフライン検証結果連動試験に先立ち, オフ ライン検証として，実績データを取り込みながらも発電機 を実際には制御しない状態で EDC 計算を行い，手動制御 結果と比較した。この目的は, 計算精度と経済性の確認で ある。

この検証により, $\mathrm{AFC}$ 容量と燃料コストについて , 以下 のトレードオフの関係にあることか確認できた。

・ $\mathrm{AFC}$ 容量を $1.4 \% \mathrm{MW} / 5$ 分確保すると 燃料費が $0.4 \%$ $1.0 \%$ 減少

- $\mathrm{AFC}$ 容量を $2.0 \% \mathrm{MW} / 5$ 分確保すると，燃料費が $0.1 \%$ $0.4 \%$ 増加

また，AFC 容量制約ならびに燃料消費量制約とも，手動制 御と比較して制約違反量が減少していることか確認できた。 今回の検証では, AFC 容量が $1.4 \% \mathrm{MW}$ の場合, 総需要予 測誤差が大きな時間帯では一時的な過不足が発生する現象 が発生したが, 総需要カーブを補正して運用すれば吸収可 能な不足量であり，経済性の向上にも大きく寄与するもの と期待される。

〈5. 2〉連動試験結果連動試験は, 半日程度の期間 に分割して数回行うことにより実施した。图 7 に 4 日分 を合成した EDC 制御結果と手動制御結果との比較を示す。 図から，制御誤差を制御目標值の範囲に保ちながら負荷変 動に追従できていることがわかる。また，需要急増時をふ くめて $\mathrm{AFC}$ 余力を確保しながら適正に追従できているこ


(a) EDC 制御実績
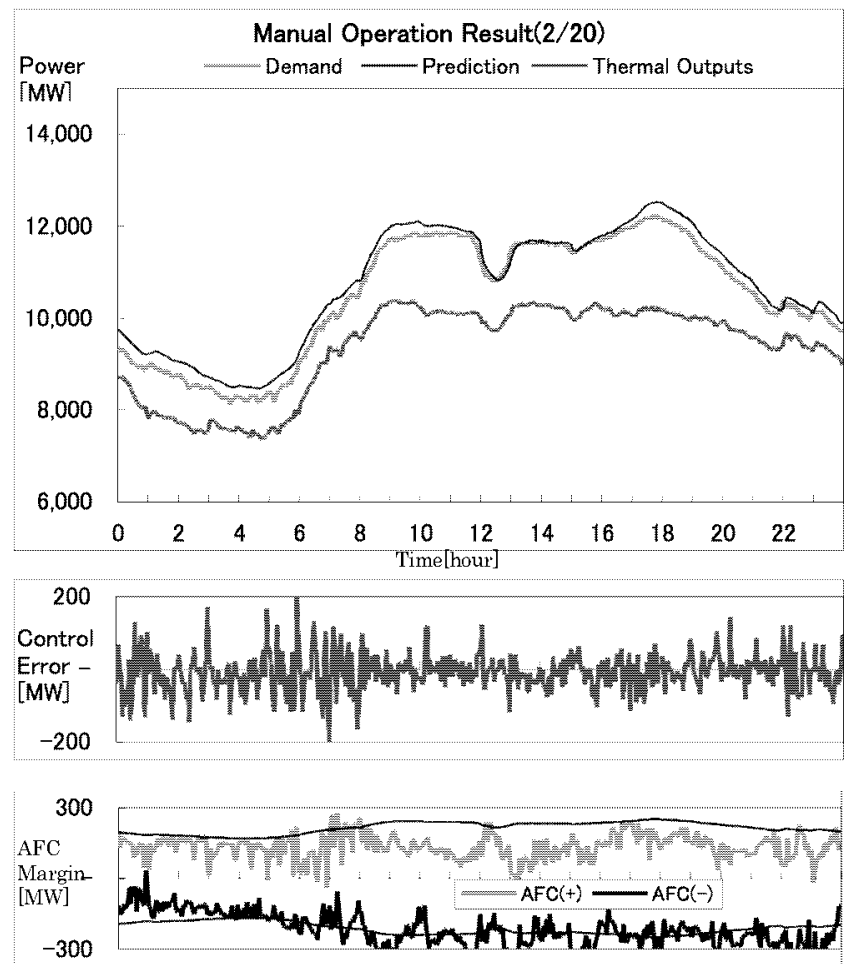

(b) 手動制御実績

図 7 手動制御と連動試験時の制御誤差・AFC 容量の比較

Fig. 7. Comparison between manual control and automatic (EDC) control.

\section{とがわかる。}

代表的な発電機（G1G5）に対する指令実績例を図 8 に 示す (縦軸 : 定格出力に対する指令值の割合で， 1.0 が定 格出力)。一般に出力配分は増分単価の順番で決まるが, 例 




(a) 朝の立ち上がりから昼休みを含む連動試験

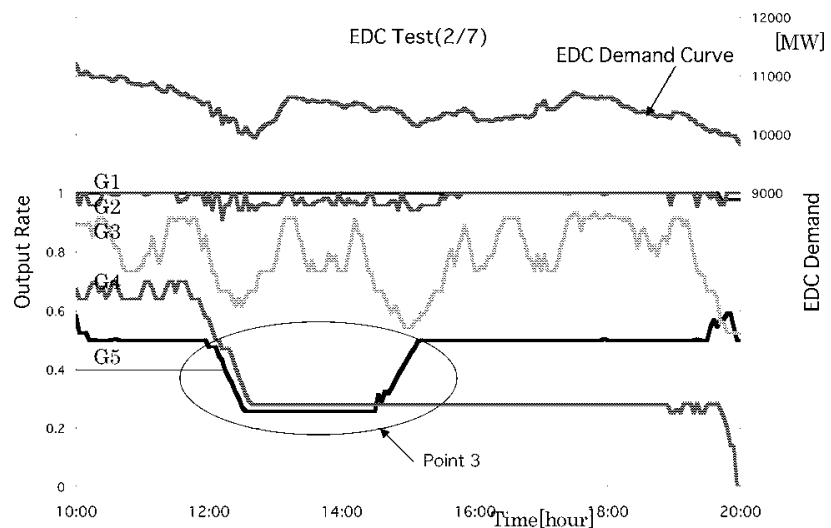

(b) 昼休みから点灯ピーク以降を含む連動試験

図 8 代表的発電機の動き

Fig. 8. Example output of representative generators.

えば (a)の Point1 のように火力分担量が急激に変化する時 間帯については, 単価の低い火力機 : G2 の出力を一旦下 げて負荷増加に合わせて再度上げることて変化速度を確保 し，適正に追従している。また，(a)の Point2 は，8 時から 火力機 : G4 が予定外の出力保持に入ったが, EDC のスケ ジュール補正機能力俲果的に機能し，単価の高い別の火力 機 : G5 を自動的に選択して出力を上げている樣子を示して いる。(b) の Point 3 は, 増分単価の高い発電機 : G4 および G5 は, 朝の立ち上がり後一旦最低出力まで落とすが, 点灯 ピークに必要となる G5 は , バンド切替え保持時間を考慮 して再度出力を持ち上げている樣子を示している。

以上の結果から,AFC 容量を確保した EDC 計算と,AFC 制御結果を $\mathrm{EDC}$ 計算にフィードバックすることにより，需 要急変時を含めて問題なく自動需給制御が可能であること が確認できた。

〈5. 3〉試運用結果連動試験の結果を受けて，2003 年 3 月から 5 月の期間を $\mathrm{EDC}$ 試運用期間としてデータを 収集した。本期間における EDC 使用比率と操作回数のグ ラフを图 9 に示す。EDC 使用比率が $20 \%$ を越えると，操作 回数か喲 $1 / 4$ と大幅に減少していることがわかる。EDC 使 用比率が $20 \%$ 程度で手動操作回数が大幅に減少するのは, ベース運転となる石炭火力等は EDC 対象としなくても最 大出力で一定であり，ミドル対応の LNG ならびに一部石



図 $9 \mathrm{EDC}$ 使用比率と手動操作回数

Fig. 9. Relation between number of manual operations and EDC rate (rate of generator under EDC).

油火力を EDC 対象とすることにより，経済的に需給バラ ンス制御が可能なためである。

\section{6. おわりに}

本論文では, 東北電力の新中央給電指令所システムに適 用した EDC 機能について報告した。今回開発した EDC の 特徵と成果は以下の通りである。

（1） EDC 問題を，離散值最適化問題と連続值最適化問 題により定式化した。これにより，自由度の高い評価関数・ 制約条件を組み込む事が可能となった。

（2） EDC 問題の解法として, 問題空間探索法と内点法 $\mathrm{QP}$ を適用することで, 将来 8 時間先までの $\mathrm{EDC}$ 計算を才 ンライン計算で行う事が可能となった。

（3） EDC 問題に AFC 容量制約を組み込むことで，コ スト増分を最小限に抑えながら, 需要変動や EDC 対象外 供給力変更による制御誤差を $\mathrm{AFC}$ 機能と協調しながら吸 収する自動需給制御が実現できた。

（4）実連動試験ならびに試験運用結果より，従来のEDC では自動制御が困難であった時間帯を含めて, 自動需給制 御による自動経济運用が可能であることが確認できた。

本 EDC 機能は, 2003 年 3 5 月の試運用期間を通じて実 用性か確認できたので, 6 月以降は実運用に使用している。 (平成 16 年 3 月 10 日受付, 平成 16 年 8 月 30 日再受付)

$$
\text { 文献 }
$$

（1）電力系統技術委員会 :「給電自動化システムの機能報告書」, 電気学 会技術報告, No.931 (B 部門) (2003)

( 2 ) M. Koshio, K. Ono, K. Hirose, and S. Nakamura: "Economic Load Dispatching Method considering Output Zone Constraint", Proc. of the Ninth Annual Conference of Power \& Energy Cosiety, IEE Japan, No.118 (1998) (in Japanese)

古塩正展・小野かずみ・広瀬公一・中村静香 : 「出カバンドを考慮し た経済負荷配分方式」, 平成 10 年電気学会電力・エネルギー部門大 
会, No.118 (1998)

( 3 ) K. Abe, T. Ishihara, Y. Satoh, Y. Kojima, K. Ono, and S. Nakamura: "New Economic Dispatching Control for Central Load Dispatching Center", Proc. of the Eleventh Annual Conference of Power \& Energy Society, IEE Japan, No.338 (2000) (in Japanese)

阿部公哉・石原 徹・佐藤佳彦・小島康弘・小野かずみ・中村静香 : 「中央給電指令所システムの新需給制御機能」, 平成 12 年電気学会電 力・エネルギー部門大会, No-338 (2000)

(4) K. Abe, T. Ishihara, O. Ishioka, Y. Kojima, and S. Nakamura: "Development of EDC considering future power flow constraint and AFC margin", The Papers of Joint Technical Meeting on Power Engineering and Power System Engineering, IEE Japan, PE-02-171 (2002) (in Japanese) 阿部公哉・石原 徹·石岡 修·小島康弘・中村静香：「多時刻断面 で潮流制約・AFC 容量制約を考慮した EDC の開発」, 電気学会電力 技術研資, PE-02-171 (2002)

( 5 ) Y. Kojima, S. Nakamura, K. Abe, O. Takahashi, E. Tsukada, and T. Kurokawa: "Development of EDC considering Co-operation with AFC", The Papers of Joint Technical Meeting on Power Engineering and Power Systems Engineering, IEE Japan, PE-03-35 (2003) (in Japanese) 小島康弘・中村静香・阿部公哉・高橋 修·塚田英一・黑川隆久 : $\ulcorner\mathrm{AFC}$ との協調制御を考慮した EDC の実運用化」, 電気学会電力技 術研資, PE-03-35 (2003)

（6）中村静香：「最急降下法を用いた問題空間の探索一電力系統復旧へ の適用一」, 電気学会電力技術研資, PE-91-33 (1991)

小 島 康 弘 (正員) 1966 年 1 月 10 日生。1990 年大阪大学大


学院工学研究科修了。同年 4 月, 三菱電機 (株) 入社。現在, 先端技術総合研究所にて主として電 力流通システムの制御・最適化に関する研究に従 事。IEEE 会員。

中 村 静 香 (正員) 1949 年 3 月 31 日生。1973 年 3 月成蹊

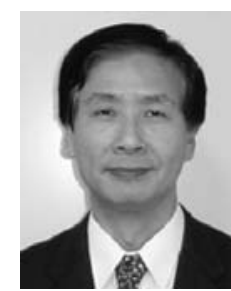
大学大学院工学研究科修士課程修了。同年 4 月三 菱電機 (株) 入社。主として, 電力系統への最適 化技術の適用に関する研究・開発に従事, 現在に 至る。工学博士 (東北大)。1990 年オーム技術賞。 情報処理学会会員。
阿 部 公 哉 (正員) 1964 年 6 月 2 日生。1988 年 3 月東北大

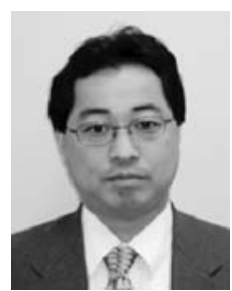
学工学部電気工学科卒業。同年 4 月東北電力 (株) 入社。主として電力系統の制御・運用技術に関す る業務に従事。

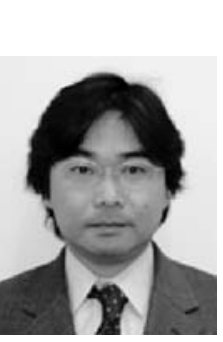

(正員) 1963 年 11 月 8 日生。1986 年 3 月早稲 田大学理工学部電気工学科卒業。同年 4 月東北電 力 (株) 入社。主として電力系統の制御・運用技 術に関する業務に従事。



(正員) 1954 年 1 月 21 日生。1979 年 3 月東京 工業大学大学院理工学研究科修士課程修了。同年 4 月東北電力 (株) 入社。主として電力系統の制 御・運用技術に関する業務に従事。

黒川隆 久 (正員) 1963 年 12 月 15 日生。1987 年 3 月北海 道大学工学部電気工学科卒業。同年 4 月三菱電機 (株) 入社。主として電力系統監視制御システムの 開発に従事。2002 年 10 月ティーエム・ティー・ アンドディー (株) に出向。 